Bulgarian Academy of Sciences. Space Research and Technology Institute.

Aerospace Research in Bulgaria. 33, 2021, Sofia

DOI: https://doi.org/10.3897/arb.v33.e15

\title{
HUMAN RELIABILITY INCREASING APPROACH IN AIRCRAFT MAINTENANCE TECHNICIAN'S TRAINING PROCESS
}

\author{
Angel Tanev \\ Sensata Technologies Bulgaria Ltd. \\ e-mail:ang_tanev@abv.bg
}

Keywords: human reliability, aircraft maintenance, optimal control, utility function.

\begin{abstract}
This article presents an approach for increasing the maintenance technician's reliability by considering the human fault rate as utility function's maximization problem in the technician's training process. Adequately trained technicians are capable to perform a maintenance and manage the reliability of their assigned assets within the complex aircraft systems. In general, a degradation of aircraft reliability, due to maintenance tecnician's competency, typically leads to significant, undesirable safety and economic consequences. In this article, an optimal control theory is applied on the purpose of finding of a fault rate reduction series in the training process which leads to highest technician's reliability in the maintenance process of the complex aircraft systems.
\end{abstract}

\section{Introduction}

Aircrafts equipment and systems are becoming more complex, as well as the associated cost is significantly increasing due to loss of operation in case of failure. In aviation domain, four aspects are considered - reliability, maintainability, availability and safety (RAMS). From theoretical background point of view and practical observations, the reliability level is decreasing by accumulating the time in the field. Therefore, it is very important to keep an aircraft reliability above a critical (lower) level to not compromising the aviation safety. Aviation safety is a domain which is being threated by many agents [1]. One should note that, on one hand, errors related to maintenance can be more difficult to detect and, on other hand, they have the potential to affect the safe operation of aircraft for some time period. Technical/maintenance failure emerged as the leading cause of airline accidents and fatalities [2]. Improperly trained maintenance technicians is one of the contributing factors to aircraft accidents [4]. Some authors describe about US National Transport Safety Board (NTSB) reports related to deficient maintenance of $50 \%-7$ out of 14 airline accidents [2]. Another analysis on the accidents in the period 1990-2006, done by EASA, shows the major cause was maintenance [5]. International Air Transport Association (IATA) 
safety report stated on average about $10 \%$ were maintenance events which led to aircraft accidents (2009-2013) [6]. For the same time period, maintenance operations together with training systems were highlighted to be a latent cause for 27 out of 338 non-fatal accidents [6]. Another study shows that maintenance factors $(6 \%)$ take the third rank [7]. IATA (2003-2008) stated that incorrectly performed maintenance was a primary cause for $30 \%$ (on average) of the registered worldwide accidents with aircrafts [8]. Another study from Boeing shows that 20\% of the accidents contained maintenance or inspection action [3]. In United Kingdom, Civil Aviation Authority (CAA) has reported that $10 \%$ of recorded events are maintenance related. For 10 years period (1996-2006): 51.1\% were assigned to incorrect maintenance actions, $26.2 \%$ to ineffective maintenance control and $20.7 \%$ to incomplete maintenance [9]. Some other studies focused on fatality of maintenance related accidents. For the time period between 1999 and $2008,26.7 \%$ of all fatal accidents were maintenance related [4].

Maintenance errors do not only cause safety issues but also have significant economic impact and they are very costly to the industry. Maintenance errors may cause, for example, aircraft unavailability, in-flight shut downs, maintenance rework, maintenance equipment damage and injury to maintenance personnel. Some estimations show a cost of USD 500000 (per engine in-flight shutdown) [1].

The growing demand for maintenance personnel will require highly qualified technicians. For example, the need for Europe region will be approximately 130000 new technicians who should be available to maintain the new aircrafts during the next 20 years [1].

One can conclude that the human's reliability is a very important part of aircraft/aerospace systems reliability and safety, for example, see [10-17]. However, many studies in that area do not consider utility function and dynamic optimization in their modelling. The main goal of the proposed study is to find an approach how to increase the technician's reliability by considering the fault rate as utility function's maximization problem in the technician's training process.

\section{Theoretical Background}

Suppose a maintenance technician's full working capability restoration after a dedicated technical training where the probability of fault-free operating for a given time $t$ is defined by the following expression [19]:

$$
R_{0}(t, \tau)=e^{-\int_{0}^{t} \lambda(z, \varepsilon) d z \cdot e^{-j o(l, \xi) d l .}}
$$

By analogy to the reliability theory, the term under the first exponent is associated with the technician's reliability [19]: 


$$
R(t, \varepsilon ; \tau, \xi)=\int_{0}^{t} \lambda(z, \varepsilon) d z \cdot e^{-\int_{0}^{\tau} v(l, \xi) d l .}
$$

$\int_{0}^{t} \lambda(z, \varepsilon) d z=q(t, \varepsilon)$

In (2) the first term ${ }^{0}$

is called an exhausted reliability for a time

t under conditions $\varepsilon$ [19]. The second term

$$
\gamma(\tau, \xi)=\int_{0}^{\tau} v(1, \xi) \mathrm{d} 1 \text { is }
$$

is called a restored reliability which is obtained in the technician's training process for a time $\tau$ under conditions $\xi$. The technician's reliability can be then expressed in the following simplified way [19]:

$$
R_{0}(t, \tau)=e^{-q \cdot e^{-\gamma}}=R_{0}(q, \gamma)
$$

After reviewing (3), one can make a conclusion that the technician's reliability $R_{0}(q, \gamma)$ is decreasing when the exhausted reliability $\mathrm{q}$ is higher, and $R_{0}(q, \gamma)$ is increasing when the restored reliability $\gamma$ is higher.

Let's consider in our case study the following problem - the restored reliability

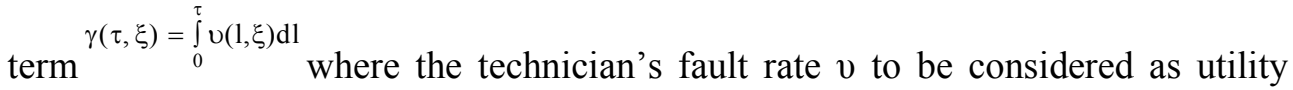
function which needs to be maximized on the purpose of obtaining as high as possible technician's reliability in the training process. An optimal control theory (dynamic optimization) will be further applied to solve this problem.

Nowadays, the applied mathematical modeling (e.g. applied optimization) is widely used in many research areas - for example, see [18, 20].

First, suppose an optimal control task defined over the following frame with periods: $0,1,2, \ldots \mathrm{T}$ [18]. The general consideration is that the state variable ${ }^{x_{t}}$ is measured at the beginning of each period $t_{\text {and }}$ the control variable $u_{t}$ is applied during this period $t$. Fig. 1 shows this problem statement:

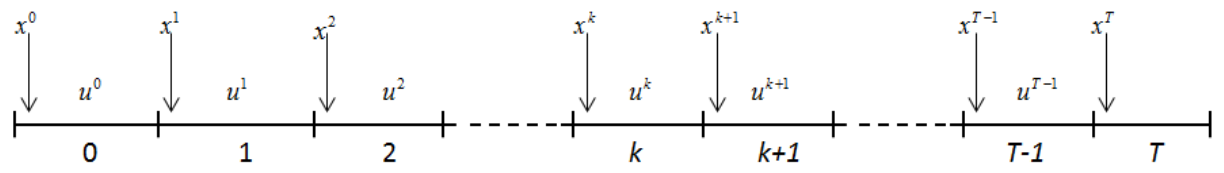

Fig. 1. Discrete time optimal control problem

with some functions which are continuously differentiable: 
$f: E^{n} \times E^{m} \times \Theta \rightarrow E^{n}, F: E^{n} \times E^{m} \times \Theta \rightarrow E^{1}, g: E^{m} \times \Theta \rightarrow E^{s}, S: E^{m} \times \Theta \cup\{T\} \rightarrow E^{1}$

The modeling of the problem stated above can be done in the following way [20]:

$$
\max \left\{J=\sum_{t=0}^{T} F\left(x_{t}, u_{t}, t\right)+S\left(x_{T}, T\right)\right\}
$$

where: the above expression (4) is a subject to the following constraints:

$$
\begin{aligned}
& \Delta x_{t}=x_{t+1}-x_{t}=f\left(x_{t}, u_{t}, t\right), t=0,1, \ldots, T-1 \\
& x_{0} \text {-given } \\
& g\left(u_{t}, t\right) \geq b_{t}, t=0,1, \ldots, T-1
\end{aligned}
$$

However, in the real practice, due to some feasibility reasons, it is impossible to have records in continuous time. Therefore, having a daily information, the time series of fault rate control can be expressed as [20]:

$$
\vec{u}=\left\{u_{0}, u_{1}, u_{2}, \ldots ., u_{T}\right\}
$$

Next, supposing the total time period in our case study $\mathrm{T}=10$ days (i.e. the scheduled techncian's training period is 10 days), the objective function in our optimization problem can be expressed by [20]:

$$
V\left(x_{0}, \vec{u}\right)=\sum_{t=0} \rho C\left(u_{t}\right)
$$

where: $C\left(u_{t}\right)$ - cash flow for $t$-th day;

$$
\begin{aligned}
& \beta=1 /(1+r)-\text { discounting factor; } \\
& r-\text { the interest rate. }
\end{aligned}
$$

From a financial theoretical background point of view, (7) can be considered as net present value (NPV) and in many practical tasks can be modeled with a power function [20]:

$$
V\left(x_{0}, \vec{u}\right)=\sum_{t=0} \rho u_{t}^{\alpha}
$$


To maximize the objective function (8), the qualified trainer/instructor can decide to apply the time series of fault rate control in (6) with a constraint shown on equation (9) [20]:

$$
x_{t+1}-x_{t}=-u_{t}
$$

To proceed further with the task, a numerical solution to a problem related to dynamic optimization requires two endpoint conditions. Suppose the technician's initial fault rate is 2.5 [1/day] and the trainer/instructor has planned to deliver the training for time period of 10 days. Then in this case study are assumed: the initial condition $x_{0}=2.5[1 /$ day $]$ and final one $x_{T}=x_{10} \geq 0$.

\section{Results and discussion}

The task described above is solved by using Microsoft Excel ${ }^{\circledR}$ software where expressions (1) - (9) are introduced in a spreadsheet format. In Table 1 are shown the inputs together with the equations listed in the theoretical chapter:

Table 1. Inputs for our case study

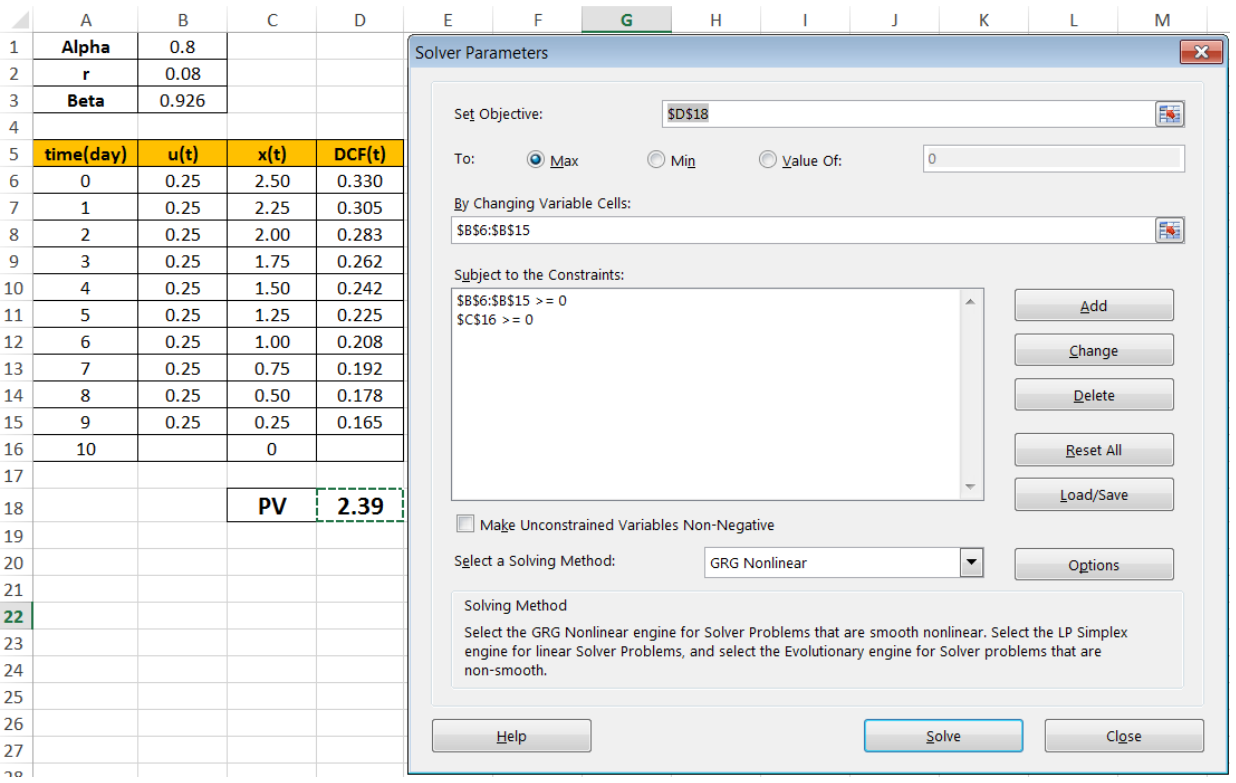

As a starting point, the inputs in our study: $\alpha$ (see (8), note: $0<\alpha<1$ ) and the interest rate $\mathrm{r}$ are assumed to be 0.8 and $8 \%$ respectively. The cell B3 in Table 1 is dedicated on computing the discounting factor in (7). The equation (9) is implemented in column $\mathrm{C}$ which represents the time series of the technician's fault 
rate. At the beginning of each day, the fault rate is equal to the fault rate of the beginning of previous day minus the reduced fault rate in previous day (see (9)).

The initial fault rate is $x_{0}=2.5$ [1/day] which is shown in cell C6. Applying "Solver" algorithm introduced by Microsoft Excel® which requires initial guess values of the optimal time series of fault rate. And at 1 st iteration, suppose that the fault rate is controlled uniformly each day, for example, with 0.25 [1/day] (cells $\mathrm{B} 6: \mathrm{B} 15$ in Table 1). In the column $\mathrm{D}$ in spreadsheet is shown the $\mathrm{DCF}(\mathrm{t})$ which stands for discounted cash flow gained during day t, i.e. $\beta^{t} u_{t}^{\alpha}$. The cell D18 shows the net present value denoted by (8).

The NPV given by (8) depends on the initial fault rate ${ }^{x_{0}}$ and on the fault rate control $\vec{u}$, i.e. $V\left(x_{0}, \vec{u}\right)=2.39$ if $x_{0}=2.5$ and uniform fault rate series of 0.25 [1/day]. One may conclude in that case the uniform fault rate series is not optimal when the future cash flows are subject to discounting factor. Applying the optimization algorithm in that case, the optimal fault rate series $\vec{u}$ can be found which maximizes the NPV in (8). The non-negative constraints on control and state variable can be seen in the "Solver's dialog box (see Table 1).

The results are now shown in Table 2 . Then the optimal fault rate reduction series is: 0.82 [1/day] in day $\mathrm{t}=0 ; 0.56[1 /$ day] in day $\mathrm{t}=1 ; 0.38[1 /$ day $]$ in day $\mathrm{t}=$ 2 ; etc. In that case of the optimal fault rate series is applied, and then the global objective function (cell D18) increases from 2.39 up to 2.60. It is interesting to highlight that the optimal fault rate series is with a slope that is declining due to the fact that the discounting factor accelerates the technician's fault rate reduction.

Table 2. Optimal solution for fault rate reduction

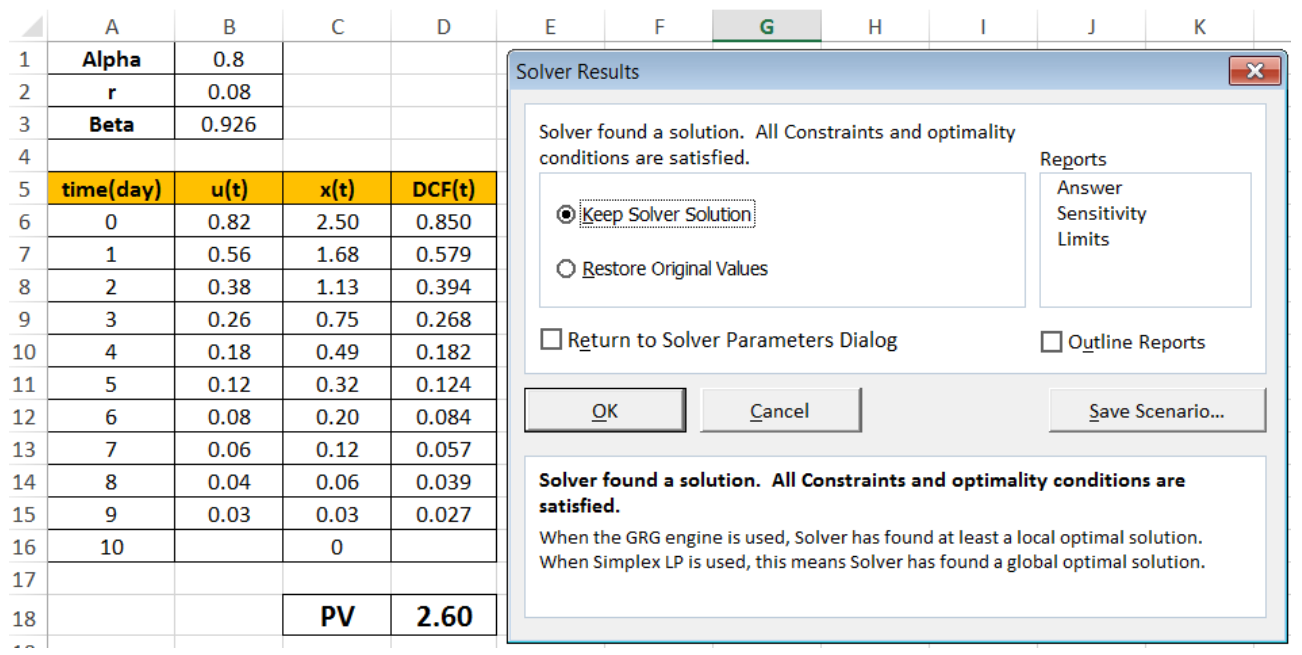


Let's now perform some sensitivity analysis, i.e. to highlight the influence of the interest rate over the optimal solution- going back to Table 1 to change the interest rate (cell B2), and then again running "Solver" algorithm. Table 3 shows the new optimal solution.

By choosing an increased interest rate- this accelerates faster fault rate reduction: 0.96 [1/day] for day $t=0 ; 0.59$ [1/day] in day $t=1$; then smaller reduction with respect to the modified interest rate $(0.1)$. The new optimal fault rate series is with higher slope since the future cash flows are discounted with higher value. The NPV increases up to 2.52 with the new optimal series. In this case, the higher discounting value is impacting the DCF value which is 2.52 , even with optimal values.

\section{Table 3. Case with modified interest rate}

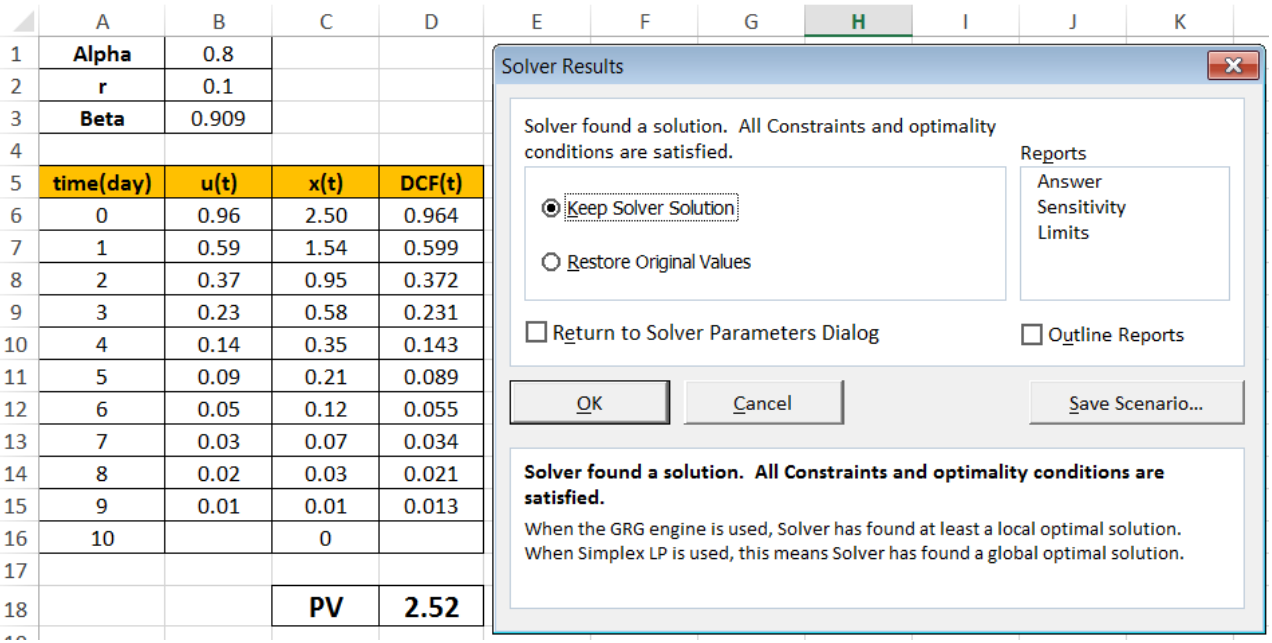

We need to highlight that significant factors impacting the optimal fault rate control are the discounting factor which induces that the fault rate has to be reduced faster. However, this effect is suppressed by the decreasing returns of the daily cash flow.

Reviewing now Table 4 which is showing the optimal fault rate series for the case when the input $\alpha$ is modified: from 0.8 to 0.85 and the "Solver" algorithm is started again- here the new optimal fault rate series is even steeper: 1 [1/day] for day $\mathrm{t}=0 ; 0.6$ [1/day] for day $\mathrm{t}=1 ; 0.36$ [1/day] for day $\mathrm{t}=2$; etc. It should be noted that approximately $80 \%$ from the (initial) fault rate is expected to be reduced over the first 4 days of the technician's training. 
Table 4. Case with modified "alpha” parameter

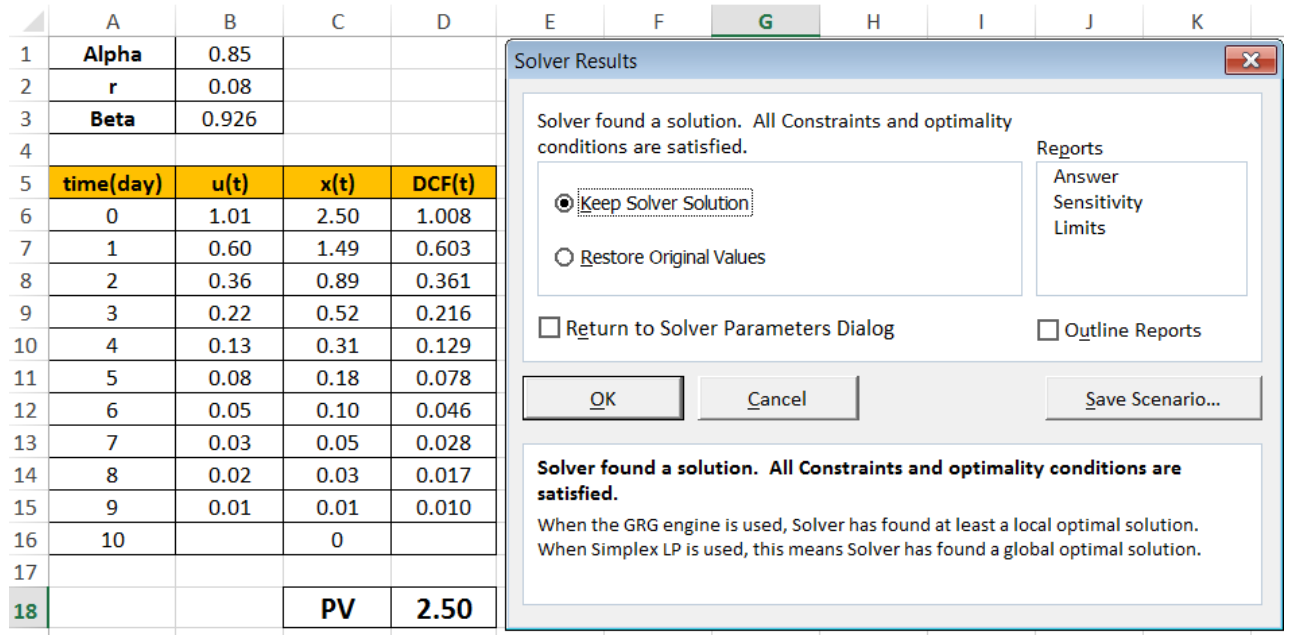

Let's consider a numerical example of a restored reliability computationsee second term ${ }^{\gamma(\tau, \xi)}=\int_{0}^{\tau} v(1, \xi) \mathrm{dl}$ of (3). Consider the results summarized in Tables 1 and 2: uniform series of fault rate reduction vs optimal fault rate reduction seriesthe fault rate vs training day is plotted in Fig. 2:

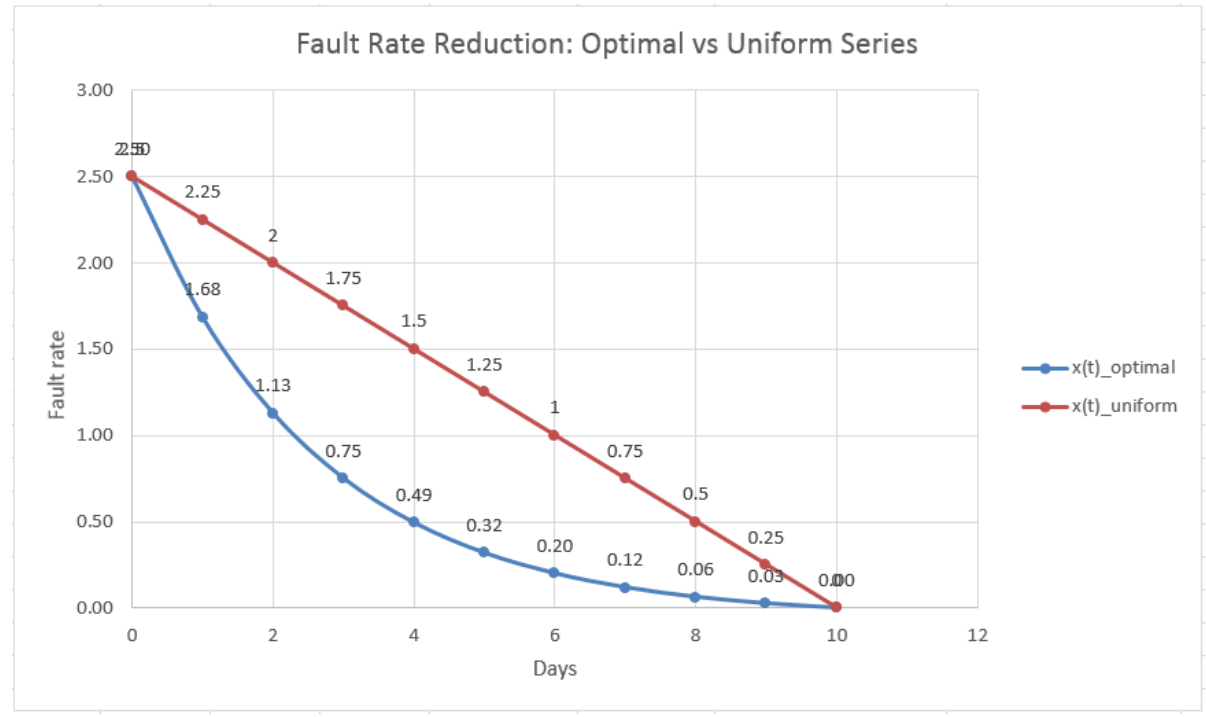

Fig. 2. Fault rate reduction vs training days 
The restored reliability $(\exp (-v t)$, where: $v$-fault rate[1/day] at day $t)$ of uniform vs optimal fault rate series is plotted in Fig. 3. One can conclude that in case of optimal fault rate reduction series the restored reliability has a steeper slope (i.e. increasing faster) than the case with uniform fault rate reduction series:

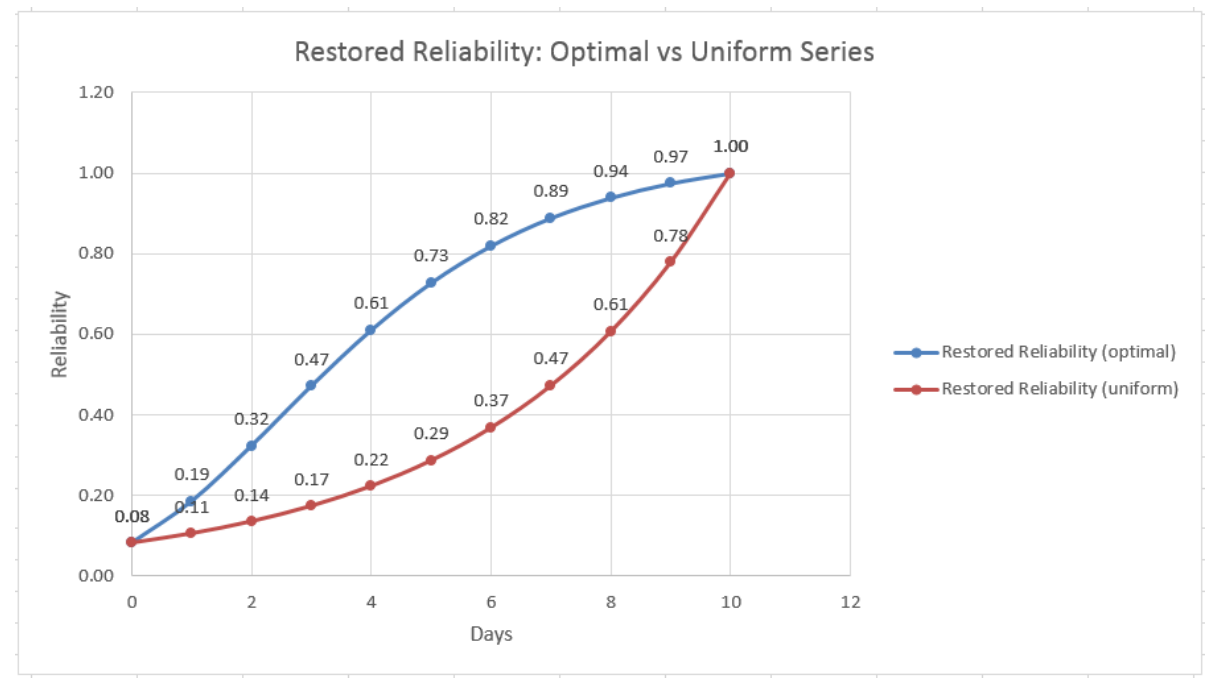

Fig. 3. Restored reliability vs training days

\section{Conclusion}

In this section, I would like to summarize some of the most important outcomes obtained by the proposed research study which are:

Maximized technician's utility function (8) requires an optimal fault rate control series $\vec{u}$ during the considered technician's training period.

The increasing in the technician's restored reliability shows steeper slope for the case of optimal fault rate reduction series compared to uniform fault rate reduction series (Fig. 3). For example, 63\% of restored reliability in case of an optimal fault rate reduction series is obtained at about $t=4$ days while in case of an uniform fault rate reduction series this value is obtained at about $\mathrm{t}=8$ days.

The influence of the interest rate over the optimal solution has been analyzed via performing a sensitivity study. Faster fault rate reduction can be accelerated by increasing the interest rate (Table 4): approximately $80 \%$ from the (initial) fault rate is expected to be reduced during the first 4 days of the technician's training.

The proposed study suggests an overlapping between today's very important and modern subjects like financial modeling, applied optimization and human reliability. 


\section{References}

1. Dalkilic, S., Improving aircraft safety and reliability by aircraft maintenance technician training, Journal Engineering Failure Analysis, 2017, 82, 687-94, Elsevier.

2. Hobbs, A., An Overview of Human Factors in Aviation Maintenance. Australian Transport Safety Bureau, (December, 2008) (ISBN 978-1-921490-93-4).

3. Safety Regulation Group, CAA, CAP 716 Aviation Maintenance Human Factors (EASA/JAR145 Approved Organisations).http://www.caa.co.uk/docs/33/C AP716.pdf, (2003) (accessed 09.10.15).

4. Marais, K. B., M. R. Robichaud, Analysis of trends in aviation maintenance risk: an empirical approach, Reliab. Eng. Syst. Saf. 2012, 106, 104-18.

5. EASA, Guidance on Safety Hazard Identification,http://www.easa.europa.eu/essi/docu ments/ECASTSMSWG-GuidanceonHazardIdentification.pdf, (2009)

6. Safety Report 2013, International Air Transport Association, Montreal, 2013 (ISBN 978-92-9252-349-7).

7. Federal Aviation Administration, Introduction to Maintenance Error Analysis. http://www.faa.gov/about/initiatives/maintenance_hf/library/documents/medi a/hfa cs/1_intro-duction.pdf, (2014).

8. IATA Safety Report, 2013. http://www.iata.org/publications/Documents/iata-safetyreport-2013.pdf,.

9. Safety Regulation Group, CAA, CAP 2009/05, Aircraft Maintenance Incident Analysis. http://www.caa.co.uk/docs/33/2009_05.pdf, (2009).

10. Erjavac, A. J., R. Iammartino, and J. M. Fossaceca, "Evaluation of preconditions affecting symptomatic human error in general aviation and air carrier aviation accidents," Reliability Engineering \& System Safety, vol. 178, pp. 156-163, 2018.

11. Calhoun, J., C. Savoie, M. Randolph-Gips, and I. Bozkurt, "Human reliability analysis in spaceflight applications," Quality and Reliability Engineering International, vol. 29, no. 6, pp. 869-882, 2013.

12. Getsov, P., Yordanov D., (2018). "Modeling the emergency situation with a failure of the engine and asymmetric thrust on a transport aircraft with two engines", International scientific conference of "Aviation Faculty", D. Mitropoliya, 19-20 April 2018, 97-102. (In Bulgarian)

13. Getsov, P., Mardirosyan G., (2018), "Aspects and application of space technology", Proceedings of scientific conference of NMU "Vasil Levski, V. Tarnovo, 14-15 June 2018, 42-53. (In Bulgarian)

14. Getsov, P., (2018). "Bulgarian contribution to space research", International scientific conference of "Aviation Faculty", D. Mitropoliya, 19-20 April 2018, 17-25. (In Bulgarian)

15. Getsov, P., Hubenova Z., "Reliability study of operators within a complex ergatic system", Journal scientific and applied research, 2014, 5, 7-14.

16. Getzov, P., Z. Hubenova, D. Yordanov, W. Popov. Modeling of the human-operator in a complex system functioning under extreme conditions, Journal Aerospace Research in Bulgaria. 2013, 25, 206-27, Sofia.

17. Gindev, E. Introduction of Reliability Engineering. Sofia: Marin Drinov, 2001.

18. Suresh, P. Sethi, Gerald L. Thompson. Optimal control theory: applications to management science and economics. Berlin: Springer, 2006. 
19. Smagin, V. A., Modely nadezhnosti zhivogo organizma (operatora), http://sir35.narod.ru/Cmagin/MODEL_04032.htm\#Beg (in Bulgarian)

20. Petrov, N., Tanev A. Optimal Control of Natural Resources in Mining Industry, International Journal of Mining Science and Technology, 2015, 25, 2, 193-98, Elsevier.

\title{
ПОДХОД ЗА ПОВИШАВАНЕ НА НАДЕЖДНОСТТА НА ЧОВЕКА ПРИ ТРЕНИРОВЬЧНИЯ ПРОЦЕС НА ТЕХНИЦИТЕ ЕКСПЛОАТИРАЩИ АВИАЦИОННА ТЕХНИКА
}

\begin{abstract}
Ангел Танев
Резюме

Статията представя подход за повишаване на надеждността на техника по експлоатация на авиационна техника, като разглежда интензивността на грешките на човека като проблем на оптимизация на функция на полезност в процеса на обучение на техника. Адекватно обучените техници са в състояние да извършват поддръжка и да управляват надеждността на възложените им активи. Като цяло, влошаването на надеждността на авиационната техника поради некомпетентността на техника за техническо обслужване обикновено води до значителни, нежелани последици свързани с безопасността и икономически загуби. В тази статия е приложена оптимална теория за управление с цел намиране на серия на редуциране на грешките в процеса на обучение, което води до най-висока надеждност на техника при експлоатация на сложните авиационни системи.
\end{abstract}

